Chemical Corp., is acknowledged. The authors also wish to thank D. W. Smith and J. B. Hess for valuable discussion, and P. P. Zeigler, Director of Research, for permission to publish this work.

\section{References}

${ }^{1} \mathrm{~J}$. D. Jevons: The Metallurgy of Deep Drawing and Pressing (1942) p. 89. Chapman \& Hall.

${ }^{2} \mathrm{M}$. Whitaker: The Deep Drawing of Non-Ferrous Metals. Sheet Metal Industries (1950) 27, No. 281, p. 815.

${ }^{3}$ M. Cook and T. LL. Richards: The Structural Changes Effected in 70:30 Brass Strip by Cold Rolling and Annealing. Journal Inst. Metals (1943) 69, p. 351.

M. Cook and T. LL. Richards: Directional Characteristics of Single-Texture-Structure Copper Strip. Journal Inst. Metals (1943) 69, p. 201.

W. M. Baldwin, Jr., T. S. Howald, and A. W. Ross: Relative Triaxial Deformation Rates. Trans. AIME (1946) 166, p. 86; Metals Technology (September 1945).

${ }^{6} \mathrm{~L}$. Bourne and R. Hill: On the Correlation of the Directional Properties of Rolled Sheet in Tension and Cupping Tests. Philosophical Magazine (1950) 41, p. 671.

${ }^{7}$ R. Hill: A Theory of the Yielding and Plastic Flow of Anisotropic Metals. Proc. Royal Soc. (1948) 193A, p. 281.

${ }^{8}$ H. Hu, P. R. Sperry, and P. A. Beck: Rolling Textures in Face-Centered Cubic Metals. Trans. AIME
(1952) 194, p. 76; Journal of Metals (January 1952). ${ }^{9} \mathrm{P}$. A. Beck and H. Hu: Annealing Textures in Rolled Face-Centered Cubic Metals. Trans. AIME (1952) 194, p. 83; Journal of Metals (January 1952).

${ }^{10} \mathrm{D}$. W. Smith: Symposium of Radiography and X-ray Diffraction. (1937) ASTM Philadelphia.

${ }^{11}$ E. W. Palmers and C. S. Smith: Effect of Some Mill Variables on the Earing of Brass in Deep Drawing. Trans. AIME (1942) 14\%, p. 164.

${ }^{12}$ W. H. Bassett and J. C. Bradley: Ears on CuproNickel Cups. Trans. AIME (1933) 104, p. 181.

${ }^{13} \mathrm{~F}$. H. Wilson and R. M. Brick: Textures, Anisotropy, and Earing Behavior of Brass. Trans. AIME (1945) 161, p. 173.

${ }^{14} \mathrm{M}$. Cook and T. LL. Richards: The Influence of Crystal Structure on the Cold Rolling and Annealing of Copper Strip. Journal Inst. Metals (1941) 6\%, p. 203.

${ }^{15} \mathrm{~A}$. Hone and E. C. Pearson: Grain Orientation in Aluminum Revealed by Anodic Film. Metal Progress (1948) 53, p. 363; also Metal Progress (1950) p. 713.

${ }^{16} \mathrm{P}$. Lacombe and L. Beaujard: Etude Microscopique de l'ecrouissage et de la recrystallisation de l'aluminium extra-pur. Revue Metallurgie (1947) 44, p. 71.

${ }^{17}$ W. M. Baldwin, Jr.: Effect of Rolling and Annealing upon the Crystallography, Metallography, and Physical Properties of Copper Strip. Trans. AIME (1946) 166, p. 591.

${ }^{18} \mathrm{~T}$. LL. Richards: Preferred Orientation in NonFerrous Metals. Progress in Metal Physics (1949) Vol. 1. London. B. Chalmers.

Technical Note

\title{
Preferential Etch for Use in Optical Determination Of
}

\section{Germanium Crystal Orientation}

\author{
by R. H. Wynne and Colman Goldberg
}

W HEN using an optical goniometer to determine crystal orientation ${ }^{1}$ it is advantageous to use a preferential etchant so that the etch pits have plane faces which are parallel to crystallographic planes, all of which are of the same "form."

"Westinghouse Silver Etch" (WAg), a preferential etch for germanium, is made up as follows: 40 $\mathrm{ml}$ of 49.7 pet hydrofluoric acid, $20 \mathrm{ml}$ of 70.7 pet nitric acid, and $40 \mathrm{ml}$ of distilled water containing $2.0 \mathrm{~g}$ of silver nitrate. Examination of metallographs of WAg etched surfaces (Fig. 1, for example) indicates that, regardless of crystal orientation, the faces of the etch pits are (111) surfaces. Optical goniometer examination of these WAg etched surfaces also indicates that the faces of the etch pits are (111) surfaces, i.e., all bright reflections are from (111) planes.

When using an optical goniometer of the type described by Barrett, ${ }^{1}$ not only (111) reflections from a WAg etched germanium surface but also other reflections of lower intensity will be observed. These latter reflections can cause confusion. We have used an optical goniometer made from a war surplus astrocompass and a galvanometer lamp. The reflections are observed by using the goniometer in a darkened room and letting the reflected light be in-

R. H. WYNNE and C. GOLDBERG are associated with the Electronics and Nuclear Physics Dept., Westinghouse Research Laboratories, East Pittsburgh, Pa.

TN 146E. Manuscript, Oct. 16, 1952.

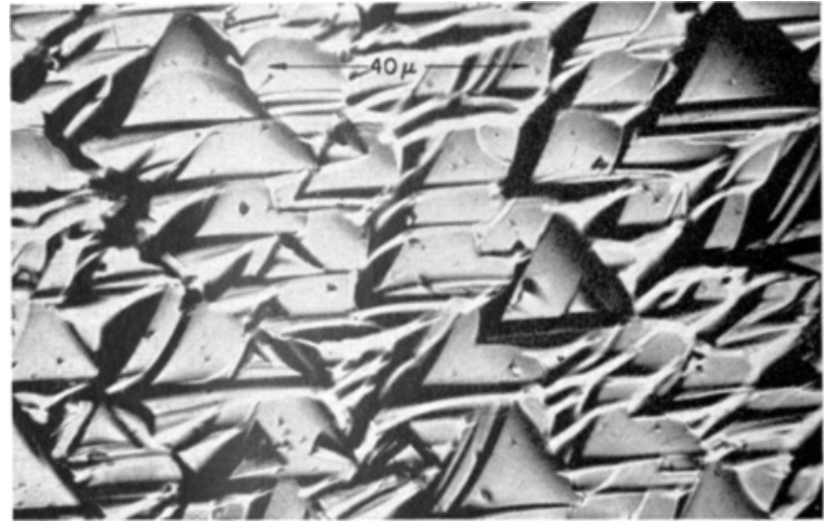

Fig. 1-WAg etched germanium surface. Approximately (111) orientation.

cident upon a piece of white paper. The resulting decrease of goniometer sensitivity enables (111) reflections only to be observed. This in turn permits the crystal orientation to be determined in a matter of minutes, since only two measurements are necessary.

The authors wish to acknowledge the help received from R. E. Davis who assisted in making the metallographs and aided the authors in the interpretation of the metallographs.

${ }^{1}$ C. S. Barrett: Structure of Metals (1943) pp. 173-177. New York. McGraw-Hill Book Co. 